\title{
Toward the Public Goods Provision in the Early Modern Economy
}

\author{
Masayuki Tanimoto
}

WHY "PUBLIC GOODS"?

Historically, to sustain and reproduce their economic lives, people have obtained goods and services in various ways. Although market transactions have taken a central position in the present economy and historical research has tended to stress this feature of economies due to an interest in economic growth, we must consider the possibly significant roles of nonmarket activities in the economy in order to grasp the entire picture of people's lives in history as well as the present world. How did people tackle issues that the market did not handle well? To what extent did their approach to finding solutions to their economic challenges reflect their political and social institutions as well as the structure of their economy? The present volume explores these questions by investigating efforts made for the provision of "public goods" in early modern economies from the perspective of comparative socioeconomic history.

The concept of "public" in this volume denotes the sphere in which people obtain goods and services for their lives through neither market transaction nor direct provision based on "personal" relationships. The latter, "personal" relationships, includes the relationships between a lord and his subject as well as family or kinship ties. Thus, this concept of publicness is defined in contraposition to "market" as well as "personal"1 relationships, not in relation with the specific characteristics of providers such as government or state. The reason why we introduce the term "public goods," which originated in economics, is owing to the fact that this concept is useful in identifying our intention to use "public" in this manner. Economists conventionally define "public goods" according to their attribute of exhibiting nonrivalry and nonexcludability, traits that hinder proper provision 
through the market since providers are unable to obtain appropriate rewards due to free riders who enjoy benefits without incurring costs. As we discuss later, many of the cases we address in the present volume fail to fulfill fully the requirement of this definition, showing the attributes more of, in economics vocabulary, "club goods" (nonrivalry but excludable), "common pool goods" (nonexcludable but rivalry), or goods with positive externalities. Such expressions are cumbersome to use frequently and they share with the economist's definition of "public goods" the trait of being ill suited to market transactions, thus deserving to be regarded as "quasi-public goods" in the economist's array of more conventional concepts. The aim of this volume is to investigate how and to what extent "public goods" (hereafter without quotation mark and including "quasi-public goods") were provided to satisfy the needs for people's ordinary lives and reproduction. They are public in the sense that they are produced and distributed neither by market mechanisms nor through personal relationships, but in a political-social space including government actors and other social entities. The early modern period is suitable for considering this subject since these three components, markets, personal relationships, and a political-social space in which we find public goods (hereafter "public social space"), were sufficiently active to identify their functions in the economy, in addition to being sufficiently diverse in terms of the ways each component was weighed. The volume tries to disentangle the functions of these three components in order to identify the diversity of public goods provision across different early modern societies.

To clarify our approach in distinction to the existing literature, we first explain how we modify the concept of public goods, of the state, and of the demarcation of market and nonmarket to address features of the early modern economy. The discussions on economic development in history, specifically those linked to industrialization or modern economic growth, have paid great attention to the formation and development of the market economy as a set of institutions able to augment people's welfare, in theory by realizing the optimal resource allocation of the society. The literature that has been concerned with development in the early modern period, such as the proto-industrialization thesis ${ }^{2}$ or the Smithian growth argument, ${ }^{3}$ has revealed that actually market activities were spreading across both urban and rural sectors of the economy. The role of specific nonmarket practices for promoting the economic development and welfare has been a distinct concern, typically involving the discussion of the state's economic policies. In fact, there has been a long-standing debate regarding the role of mercantilism in early modern Europe, with recent literature reviving and even enlarging concerns about the state's roles in economic development in light of institutions and political economy (North and Weingast 1989, Acemoglu and Robinson 2012). In addition, the role of the state for augmenting the well-being of the subjects has been newly discussed in the early modern history and the fiscal state argument, apart from the viewpoint of mercantilism (Rosenthal and Wong 2011, Yun-Casalilla and O’Brien 2012, $\mathrm{He}$ 
2013, Sng and Moriguchi 2014, Vries 2015). In much of this discussion, early modern states are expected to be the main provider of public goods, which, in light of the economic theory of "market failure," were undersupplied through the market transactions. In short, the good workings of the market in the early modern economies were complemented by the contribution of the state providing public goods.

This volume looks at nonmarketed goods that only involved the government as one of several actors. Quite a few goods and services were supplied in early modern societies by various kin groups, communities, lords, and governments to sustain and reproduce the economic lives of ordinary people. It is impractical to confine our focus to the activities directly related to the state in paying attention to the role of nonmarket activities in economic life. By taking the following three fields up, all of which were apparently essential for sustaining people's lives and reproductions in the early modern economy, this volume relativizes the role of states and the market/state dichotomy present in the available literature discussing the state formation and public goods provision.

In part 3, the chapters deal with infrastructure projects such as dikes, roads, and water control facilities. If we take a dike as an example, it appears to qualify as a public good since inhabitants near the dike are to be protected equally against a flood (nonrivalrous), without excluding neighboring inhabitants (nonexcludable). Strictly speaking, however, nonexcludability is unclear, as the expected benefits from the dike are confined to the inhabitants within a specific geographical area. The smaller the area, the larger the excludability of goods provision is. Therefore, we should recognize that nonexcludability has been rather weak in most of the dike cases, and this attribute is applicable to other physical infrastructures such as roads and water control facilities, which deserve to be defined as "club goods." In contrast, part 4 deals with cases that lacked the attribute of nonrivalry. Each chapter tackles the benefits obtained from the forest where the concept of "common lands" is often applied. The common lands are open to users (nonexcludable) and are zero-sum in terms of benefits (rivalrous), fitting the criteria of what Nobel laureate Elinor Ostrom labeled "common pool goods." Furthermore, goods and services with "external effects" are not provided optimally through market mechanisms despite the fact that they are excludable and rivalrous, since the benefits and/or costs are not properly paid for by the beneficiaries or imposed on the providers. The former case may result in an undersupply and the latter an oversupply of a good. For our discussion, the positive externalities are significant because the provision of non-market-produced goods can supplement the undersupply of goods in ways that may benefit people through their external effects. Poor relief, on which chapters in part 2 focus, can be discussed from this point of view, since it is beneficial for social order and peace at the same time as it enhances individual recipients' well-being.

Thus, the attributes of goods and services discussed in the three main subjects of this book, namely, welfare policies for the poor, infrastructure construction and 
maintenance, and forest management, can be recognized under the name of public goods in a theoretically relaxed sense, requiring provision outside the market to avoid undersupply. This recognition not only allows us to weave together three subjects having their own distinct strands of literature into a common fabric of discussion, but also enables us to contextualize the role of "state" as a provider of public goods. There is a good reason that certain public goods, for example, dikes, were provided by a local governing body, not by the state, because the excludable nature of the goods could limit beneficiaries geographically. In contrast, military capabilities, a representative example of pure public goods in economics textbooks, are provided almost exclusively by states of one kind or another in the early modern period. In fact, the fiscal state argument, coined by John Brewer for England and applied by scholars to other early modern European countries, evaluates the capacity of the state mainly through its fiscal capacities to absorb major military expenses (Brewer 1989, Glete 2002, Storrs 2009). To understand more fully the role of public goods in early modern economies, it is therefore necessary to go beyond the specific subject of the state's military expenditures in order to identify the goods and services affecting the economic lives of ordinary people.

This observation leads us to consider more carefully the nature of early modern states that are understood to be both centralizing their rule by growing their capacities and exhibiting features of what the social theorist Max Weber called "patrimonial states." The evolution of absolutism in Europe, the transition from the declining Ming to the rising Qing dynasty in China, and the establishment of the Tokugawa regime in Japan all occur during the sixteenth and seventeenth centuries. In many parts of Europe, as well as in China and Japan, central governments emerged that acquired wider governing ability over their territories and provided the geographical foundations of subsequent modern national states. On the other hand, it is also apparent that a specific ruling family whose household economy was closely related to its public finance dominated the "state" in this period. Inevitably, the government's behavior tended to be influenced by the ruler's arbitrary motivations, which might be different from that of the modern fiscal or tax state, as Joseph Schumpeter argued a century ago (Schumpeter 1918/1991). For Schumpeter, the relationship between a ruler and the subject in the case of a "patrimonial state" was a personal relationship between kings or lords and ordinary people, most often farmers. If people were provided with any goods or services based on their mutual personal relationship, it is hard to apply the concept of public goods to this "transaction" even though they were provided by a patrimonial state. Thus, this influential characterization of the historical nature of the state in the early modern period prevents us from conceiving naively the state as a main provider of the public goods specifically other than military affairs. ${ }^{4}$

To open up our abilities to understand public goods provision in early modern times, we can consider how the demand side for public goods to sustain and enhance people's economic lives can be met within the social and political space 
beyond familial and personal relationships. In fact, there were diverse ways of providing for the poor, from the use of lineage ties in China to the promulgation of the Poor Law in England, that is, from the usage of personal relationship to creating space for public goods provision. Even though poverty has been a universal phenomenon throughout history, demand for public goods was triggered under specific conditions in which the poverty emerged as a problem to which social responses were deemed possible and desirable. Similar aspects can be observed in terms of the existence of common lands, as they could alternatively be enclosed to form a self-sufficient economy such as lords' landed estates or thrown into the market by establishing exclusive private property rights on each plot. Thus, it is important to notice that the magnitude of the need for public goods depends heavily on the historical context determining the width and depth of nonmarket activities organized outside of self-sufficient entities. With a consciousness of the theoretical sense of publicness, the role of public goods provision in early modern economy should be explored by identifying specific historical and sociopolitical contexts in which they emerge.

\section{COMPARATIVE APPROACH SETTING JAPAN AS A BENCHMARK}

The present volume explores the public goods provision and their diverse providers by comparing the cases in East Asia and Europe. In doing so, we have selected Japan, Germany (using early modern Prussia as a key ancestor of the late-nineteenth-century German state), and China to show three kinds of public goods provision quite different from Britain, which is conventionally understood as the paradigmatic case. This is an approach different from the major family of approaches to early modern global history that extends the tradition of comparing European historical practices to those of other world regions found in Marx and Weber and in much early modern economic history, the field in which this volume is most centrally located. In this approach to the early modern era, there are competing clusters of causal mechanisms intended to explain how Europeans came to achieve their political dominance and economic leadership in the nineteenthcentury world, a situation that moved into a twentieth-century era of American political and economic prominence and created a longer modern era dominated by Western power and wealth. Within these accounts of economic and political change the subject of public goods provision doesn't occupy a very salient position. The subject is brought up both implicitly and explicitly in the fiscal state literature by historians recounting what European states spent their revenues on, but the subject is only sometimes connected to how these expenditures affected the economy. Because Great Britain was the first industrial economy and its fiscal state focused so heavily on building an eighteenth-century navy, which was the foundation of its global reach politically and supported its economic ventures into other 
world regions, the analysis of other public goods has not seemed so important to economic change of the early modern period.

In order to relativize this influential approach, we take advantage of the rich scholarship on the Tokugawa era (1603-1868) to take Japanese public goods provision as our benchmark case. We devote part 1 of the book to a concentrated introduction to Japanese practices to form the frame of reference to consider poor relief, infrastructure, and forest management in parts 2 through 4 . Under the Pax Manchurea (the peace under the Qing dynasty) and the Pax Tokugawa regime, early modern East Asia showed sharp contrast with contemporary Europe in terms of their respective military affairs. Therefore, it is true to state that the case of Japan is well suited for a focus on nonmilitary public goods provision. Moreover, our choice is made more attractive for the following reasons. Although the fine-grained local and regional histories that are available for Japan are lesser known than their counterparts for countries in Europe, there exists a considerable literature in Japanese that supplies the foundation on which we build our framework that takes Japan as the benchmark case. The archival sources that make this possible include village documents, which originally remained in the house of the village head's descendant, as well as the official documents kept in the rulers' archives. They provide us with rich information on the economic and social situation of ordinary people, and reveal the relationship between public goods provision and the reproduction of people's lives. We think that the literature on Japanese rural history that is established on the solid archival foundation is one of the valuable resources for exploring early modern economy and deserves to be a benchmark that comparative discussion would rely on.

Regarding the village level documents, it is worthwhile emphasizing that they comprise basic administrative information such as "taxation" and the registration of residents and lands. Although no village was large in terms of area and population, comprising, very roughly, around one hundred households and five hundred individuals on average, the village was more the public governing body rather than just a private community, whose entitlement was delegated originally from the Tokugawa shogunate or daimyōs, rulers of the Tokugawa regime. It means the validity of the literature on early modern Japan is not just based on the archival advantage. Rather, it is the function of the rural village that deserves closer attention in considering providers of public goods in the early modern economies and that is most significant.

Interestingly, the autonomy of the village in terms of being the governing body evolved under the Tokugawa regime. ${ }^{5}$ Because of the deterioration of its financial situation, the Tokugawa shogunate as well as other daimyo (domain) governments reduced outlays on social welfare and infrastructure maintenance in the latter half of the Tokugawa period. On the other hand, the village, which had been authorized as the basic unit for controlling peasants by "feudal" authorities, achieved a considerable level of autonomy in administration, accompanied by the formation 
of village-level "public finance." Although historians have conventionally used "public" to refer to certain activities of the warrior classes, we distinguish our focus on the economy from their focus on issues of social order involving the shogunate, daimyōs, and their warrior vassals. The Japanese publicness developed among villagers as relations within a social space that made possible collective decisions to respond to demands emerging among themselves, as well as to those placed on them by the warrior class that ruled them.

Furthermore, the cooperative unit of villages emerged and even evolved to form a public social space beyond the administrative unit of the village. It was a loosely integrated area called Gunchū, or other name, substantialized by the development of the rural economy based on market-oriented agriculture and protoindustry. The wealthy peasant-farmers led this development and behaved as "local notables," complementing or even substituting the task of public goods provision. The recent scholarship discusses this by using the term "regional society" defined in this historical context. ${ }^{6}$ We think this recently revealed trajectory is distinct in emphasizing the role of "regional society" for public goods provision, and is expected to work as a catalyst that may clarify the focal point necessary for the comparative approach to be fruitful.

Based on this observation for the Japanese case, we can identify in Prussia people's dependence upon relationships between lords and subjects in which ordinary people had "personal" contracts with lords regarding the provision of necessities not provided through market transactions or their self-sufficient activities. The public social space emerged outside of this relationship. Here, the role of the Prussian state or its prototype in the Brandenburg Electorate mattered in the absence of a strong self-governing body such as the village present in the Japanese case. The Prussian generation of "common goods" from the ruler's side, discussed in a chapter of part 3, can be recognized in this context. The public social space in this sense enlarged as population increased between the eighteenth and nineteenth centuries, reaching an even-higher level of abstraction and generality after German unification in 1871.

The early modern Chinese state is similar to Prussia in terms of lacking any formal and relatively independent local or regional governing bodies. In fact, the chapters dealing with Chinese cases of poverty and famine relief, water control, and forest management commonly focus on the roles of the emperor and bureaucrats, addressing their policy practices and in some instances addressing the ideas underlying their behavior. On the other hand, the market transactions were much more prevalent in China even in the rural level, distinguishing it from the case of Prussia, and perhaps from Japan. Perhaps unexpectedly, the Chinese case offers a kind of early modern public goods more similar to modern meanings of public goods. The eighteenth-century Chinese state organized and funded goods outside market channels, incorporating in varied ways the efforts of lowerlevel bureaucrats and local elites to achieve public goods provision, in some ways 
anticipating some features of public goods provision more generally present in the modern era.

Thus, our comparative approach using Japan's case as the most common reference point highlights the diverse approaches to public goods provision across societies without invoking an "advanced" Western Europe as the standard of excellence against which other societies are typically found wanting. Even in the case of England, the chapter in part 2 discussing the workings of the English Poor Law in the local settings suggests the decentralized and regional nature of this nationally operating institution similar in some ways to regionally based public goods provision in Japan.

Together, our three main sites for what we consider three topics important to the economy give us alternative viewpoints from which to view the emergence of modern-era public goods. Choosing Japan as our primary reference point enables us to consider alternative ways in which early modern public goods provision was organized and how those practices became the background for modern-era developments. Our method seeks to identify the kinds of problems and opportunities to which elites and common people responded in early modern times by producing what we consider to be public goods. Furthermore, in general, to understand the varied constellations of practices occurring in different countries in the modern era, a look back at their early modern practices is useful. When we recall the typology of distinct kinds of modern welfare states noted by many scholars such as Gosta Esping-Andersen, who has written about "the three worlds of welfare capitalism," it seems inappropriate to assume naively the convergent path of public goods provision from the nineteenth century onward (Esping-Andersen 1990). Our expectation is not that modern practices remain closely similar to those of the early modern era but that modern-era features in each case can at times be seen as transformations of earlier practices, the absence of which would have made the subsequent practices less likely in one or more ways. Such an understanding supplements our conventional ways of understanding modern state formation and the place of public goods provision in that process. Certainly, it is worthwhile asking how, and to what extent, the structure of public goods provision in the early modern economy affected the diversity in public goods provision by the modern state. We will take up this subject further in our concluding chapter. The main work of the book, however, is to construct the beginnings of an early modern basis for forecasting the future into the modern and contemporary periods.

\section{NOTES}

1. Note that the term "personal relationship" in this volume does not exclude relationships based on "impersonal" foundations such as legal contracts based on the contemporary law system. The lordssubjects relationship in Prussia discussed in the following chapters exemplifies this aspect.

2. For the survey of literature, see Ogilvie and Cerman 1996/2010.

3. Mokyr 1990. For Japanese case, see an overview by Saito 2013. 
4. In considering the military action carried out by the arbitrary motivation of the state owner of kings or lords, wars and military affairs might also have been done in the "personal sphere."

5. For the details of this discussion, see the chapter 2 of this volume.

6. For overviewing this discussion, see Sawai and Tanimoto 2016, chap. 2.

\section{REFERENCES}

Acemoglu, Daron, and James A. Robinson (2012). Why Nations Fail: The Origins of Power, Prosperity, and Poverty. New York, Crown Business.

Brewer, John (1989). The Sinews of Power: War, Money, and the English State, 1688-1783. London, Unwin Hyman.

Esping-Andersen, Gøsta (1990). The Three Worlds of Welfare Capitalism. Cambridge, Polity. Glete, Jan (2002). War and the State in Early Modern Europe: Spain, the Dutch Republic and Sweden as Fiscal-Military States, 1500-1660. London, Routledge.

He, Wenkai (2013). Paths toward the Modern Fiscal State: England, Japan, and China. Cambridge, MA, Harvard University Press.

Mokyr, Joel (1990). The Lever of Riches: Technological Creativity and Economic Progress. New York, Oxford University Press.

North, Douglass C., and Barry R. Weingast (1989). "Costitutions and Commitment: The Evolutions of Institutions Governing Public Choice in Seventeenth-Century England." Journal of Economic History 49 (4).

Ogilvie, Sheilagh C., and Markus Cerman (1996/2010). European Proto-Industrialization: An Introductory Handbook. Rev. ed. Cambridge, Cambridge University Press.

Rosenthal, Jean-Laurent, and R. Bin Wong (2011). Before and beyond Divergence: The Politics of Economic Change in China and Europe. Cambridge, MA, Harvard University Press.

Saito, Osamu (2013). "Proto-Industrialization and Labour-Intensive Industrialization: Reflections on Smithian Growth and the Role of Skill Intensity." In Labour-Intensive Industrialization in Global History, edited by Gareth Austin and Kaoru Sugihara. London, Routledge.

Sawai, Minoru, and Masayuki Tanimoto (2016). Nihon Keizaishi: Kinsei kara Kindai made (Economic History of Japan: From the Early Modern Era to the Present). Tokyo, Yūhikaku.

Schumpeter, Joseph A. (1918/1991). The Crisis of the Tax State. In Joseph A. Schumpeter: The Economics and Sociology of Capitalism, edited by Richard Swedberg. Princeton, Princeton University Press.

Sng, Tuan-Hwee, and Chiaki Moriguchi (2014). "Asia’s Little Divergence: State Capacity in China and Japan before 1850." Journal of Economic Growth 19 (4).

Storrs, Christopher, ed. (2009). The Fiscal-Military State in Eighteenth-Century Europe. Farnham, UK, Ashgate.

Vries, Peer (2015). State, Economy and the Great Divergence: Great Britain and China, 1680s-1850s. London and New York, Bloomsbury Academic.

Yun-Casalilla, Bartolomé, and Patrick K. O’Brien, eds. (2012). The Rise of Fiscal States: A Global History, 1500-1914. New York, Cambridge University Press. 
